\title{
The Treasury-KPMG Econtech Modelling of the Excess Burden of Mining Taxation: Some Doubts
}

\author{
Jonathan Pincus ${ }^{1}$
}

\section{Introduction}

The Commonwealth Treasury commissioned KPMG Econtech to model the efficiency of the existing Australian tax system. The report was an input to the 2010 'Henry Review' of the Australian tax system (henceforth AFTS), and proved very influential to both it and (especially) the Rudd government's response to AFTS. That response comprised proposals for a new Commonwealth tax on mining, called the Resource Super Profits Tax (RSPT); a proposal to abolish royalties; and a proposal to reduce the rate of corporate income taxation. Subsequently, Treasury commissioned a second KPMG Econtech report to model the welfare effects of that response. ${ }^{2}$

Both of the KPMG Econtech reports used a large Computable General Equilibrium model called MM900. As a proprietary model, its full publication would depreciate its value to the owners. However, because it was an important input to major government policy decisions, Treasury should have ensured that sufficient information was made available to enable disinterested but informed outsiders to judge its quality. It is not sufficient for Treasury, through its own internal processes, to be convinced of the quality of the modelling. ${ }^{3}$ And there is no evidence that Treasury adopted a process similar to that of the Productivity Commission - which is widely regarded as 'best practice': when relying upon one model only the Commission forms an expert advisory group to question the modellers in some detail; and the Commission then publishes a summary of the comments and responses.

Central to mining-tax policy development were two notions. The first is that a tax on resource rents would produce public revenue without any disincentive

\footnotetext{
1 University of Adelaide, jjpincus@gmail.com The author is grateful for the comments of George Fane and Henry Ergas.

2 The first KPMG Econtech report, 2010a, was entitled 'CGE Analysis of the Current Australian Tax System', and will be referred to as 'CGE Current'. The second, 2010b, will be referred to as 'CGE Response'.

3 Until forced by a Freedom of Information request, Treasury refused to release its own estimates of the revenues expected from mining tax proposals (Treasury 2010a).
} 
effect or excess burden. When it came to the Petroleum Resource Rent Tax and the RSPT, KPMG Econtech assumed that this was the case; subsequently, however, Treasurer Swan disavowed the proposition. The second claim was that royalties, the main sources of mineral revenue for the states, were very inefficient. In fact, using MM900, KPMG Econtech concluded that royalties were the most inefficient of all 19 major taxes modelled (excepting gambling taxes, the inefficiency of which was likely overestimated. See 'CGE Current': 6): the average excess burden of royalties and crude-oil excise was 50 cents for each dollar of public revenue; and the marginal excess burden was 70 cents.

This paper concentrates on the KPMG Econtech modelling of royalties and the special taxes on mining profits. The published reports, 'CGE Current' and 'CGE Response', contain explanatory and expositional material, brief discussions of some of the modelling and the relevant literature, and the parameter values. But crucial data and modelling have not been released in sufficient detail for independent examination, let alone sensitivity analyses — and the reports contain no sensitivity analyses. Therefore, this paper will rely on partial equilibrium, back-of-the-envelope calculations of excess burden, using information in the reports and other public sources. ${ }^{4}$ When these calculations take account of effects on supply, and on the price of mineral exports, they suggest a very much lower excess burden than was estimated in 'CGE Current'. Moreover, the incidence tables that were provided by KPMG Econtech in 'CGE Current' themselves suggest a low excess burden.

\section{Background: 'Australia's Future Tax System'}

On 13 May 2008 the Rudd government announced an inquiry into the Australian tax system, to be chaired by Dr Ken Henry, Secretary of the Australian Treasury. ${ }^{5}$ The inquiry received over 1500 submissions, met with interested parties and conferred with tax specialists, and issued five consultation papers (but no interim report). A report on the retirement-income system was released on 12 May 2009. The final report, 'Australia's Future Tax System' (AFTS 2010), was provided to the government in December 2009, and released on 2 May 2010, simultaneously with the government's response.

Of the 138 recommendations, the Rudd government seized on one:

4 For more detailed discussion, see Ergas and Pincus (2012).

5 The other members were Greg Smith (Australian Catholic University); Dr Jeff Harmer (Secretary of FaHCSIA), Heather Ridout (Australian Industry Group), and Professor John Piggott (University of New South Wales). Support for the inquiry was mainly provided by Treasury and FaHCSIA. 
45: The current resource charging arrangements imposed on nonrenewable resources by the Australian and State governments should be replaced by a uniform resource rent tax imposed and administered by the Australian government:

a. is levied at a rate of 40 per cent, with that rate adjusted to offset any future change in the company income tax rate from 25 per cent, to achieve a combined statutory tax rate of 55 per cent;

b. applies to non-renewable resource (oil, gas and minerals) projects, except for lower value minerals for which it can be expected to generate no net benefits. Excepted minerals could continue to be subject to existing arrangements if appropriate;

c. measures rents as net income less an allowance for corporate capital, with the allowance rate set at the long-term Australian government bond rate;

d. requires a rent calculation for projects;

e. allows losses to be carried forward with interest or transferred to other commonly owned projects, with the tax value of residual losses refunded when a project is closed; and

f. is allowed as a deductible expense in the calculation of income tax, with loss refunds treated as assessable income.

Literally backed by Dr Henry, Prime Minister Rudd publicly announced the Resource Super Profits Tax (RSPT). In support of this proposal the Treasury released a paper claiming that the mining industry contributed a low and decreasing share of its profits to government. Ignoring company tax payments, this claim was based an estimate of mining profits of $\$ 91.2$ billion that, somehow, included resource rents not counted in ABS or ATO data on income liable to company tax. ${ }^{6}$

What followed was a vigorous lobbying effort by mining companies, and then semi-secret negotiations between the Rudd government and the largest three mining companies: Xstrata, BHP and Rio Tinto. On 23 June 2010, Kevin Rudd was replaced as prime minister by Julia Gillard, who announced that the RSPT

6 According to the Minerals Council (2011: 15), 'While some commentators accepted this estimate (and the resultant claims) unquestioningly, a number of others drew attention to what appeared to be anomalies. The Economics Editor of The Australian, Michael Stutchbury, observed in June 2010 that while the $\$ 91.2$ billion was 'painfully extracted' from Treasury, 'it provided scant information on how this could exceed other measures of total mining company profits: $\$ 63.6 \mathrm{bn}$, according to the Australian Bureau of Statistics' estimate of mining pre-tax operating profit, or $\$ 74.1 \mathrm{bn}$ in EBITDA (earnings before interest tax, depreciation and amortisation)'. 
would not be adopted in its original form. On 2 November 2011 the Gillard government announced the proposed RSPT replacement, the Minerals Resource Rent Tax (MRRT).

MRRT applies to iron-ore and coal projects from 1 July 2012, with a tax of 30 per cent on taxable profits less an 'extraction allowance' (equal to one-quarter of the tax otherwise payable) to 'recognise the miner's employment of specialist skills': this reduces the effective rate to 22.5 per cent. ${ }^{7}$ For existing projects, the taxable profit is to be struck after deductions relating to the value of the 'starting base'. Mining companies can choose whether to set the starting bases of their ${ }^{8}$ projects at historic cost or market value. Companies will also receive a credit of all current and future royalty payments. MRRT was projected to raise $\$ 3$ billion in 2012-13 and \$9 billion in 2013-14.

Perforce, this paper will deal only with the KPMG Econtech modelling: the modelling of the MRRT was undertaken by Treasury, and has not been released (Wilson 2012) and the Treasury's website redirects a search for 'Minerals Resource Rent Tax' to the Australian Taxation Office, where no modelling is to be found.

\section{Taxes on rent, in theory and practice}

AFTS proposed changing the tax mix to rely more heavily on levies imposed on rents of various kinds, especially land rents and resource rents. The reasoning relied upon has long been familiar in elementary economics: by definition, rents are receipts in excess of the minimum necessary to elicit supply - if it were possible to target rents and nothing else, then revenue could be collected with no excess burden. However, a mechanism needs to be devised to enable the tax authorities to distinguish rents from other returns, and to do so with perfect accuracy; or, equivalently, to identify perfectly inelastic supplies. No such mechanism can exist, because of asymmetric information. ${ }^{9}$

\footnotetext{
7 The government has never clarified why it did not simply announce a tax rate of 22.5 per cent. A possible explanation is that setting a rate of 30 per cent and giving the mining companies an extraction allowance equal to one-quarter of the tax payable makes it slightly easier to raise the effective rate to 30 per cent while claiming that this was always the MRRT rate and that all that has been done is to reduce the extraction allowance.

8 A small Policy Transition Group (2010), chaired by the Minister of Resources had advised the government on the development of this tax.

9 There are the huge administrative difficulties of trying to measure costs and revenues, and to allocate the costs of inputs that are shared by many projects to each individual project. This is illustrated by the fact that, after 24 years of operation, there remain substantial areas of dispute in tax law as to liability under the Petroleum Resource Rent Tax, including: the delineation between exploration and development activity; the treatment of indirect expenses; the precise definition of the taxing point; the requirements for substantiation of expenditure; and the precise scope for transfer of expenditure between projects. Several of these issues are the subject of current litigation, and are likely to make their way to the High Court.
} 
For natural resources, ex-ante auctions for the right to mine and sell minerals would seem to provide a clean extraction of resource rents - but even here questions arise. For example, if the auction price is to be paid in advance, then the supply of finance comes into play, and finance is not in perfectly elastic supply to the borrowers. AFTS and some of its members also worried about thin auction markets and a version of 'seller's regret' (which could lead a government to impose additional taxes or charges if the miner ends up making huge profits). ${ }^{10}$ Instead of auctions and royalties, Dr Henry advocated a version of the 'Brown tax', which became the RSPT. DEEWR (2010) claimed that 'The RSPT is world class. It sets a new benchmark for resource taxation.' Not for long: or, not in the way that DEEWR had in mind!

The Brown tax makes government a pro-rata owner of all cash flows from the project, incomings and outgoings, including the cost of finance. If implemented ex ante, the coercion that makes it a tax is that it mandates public equity in nascent projects; but the projectors would have the choice of not going ahead with the project. However, when implemented retrospectively, that choice is moot and then the Brown tax becomes the equivalent of partial expropriation of the existing projects. For a government short of revenue, a new tax on existing projects - which would fall on quasi-rents as well as on pure rents - offered the prospect of a quicker and larger access to revenue, especially following unexpected and unprecedented rises in minerals prices. Graphs like that presented by the AFTS (2010: Chart 6.1) and the government, showing royalties falling as a percentage of rising profits during a period of rapid commodity price rises, did nothing to reassure the disinterested onlooker that the government was then making a sharp distinction between pure rents and quasi-rents.

Moreover, the RSPT differed in one important respect from the Brown tax proper (and from a 'pure' system with an Allowance for Corporate Capital expenses): instead of instant refunds of 40 per cent of outlays, the companies would receive a promissory note bearing a rate of interest decided by government, not the market. As was noted at the time, when tendered as asset or collateral, such promises would be valued at a discount to face value. ${ }^{11}$

In keeping with elementary economic theory, the Rudd government, its Treasury and other departments, and Dr Henry himself, insisted that the RSPT would have no excess burden. The argument was sometimes put as follows (see, for example, DEEWR 2010): if a company maximises its profits by some set of actions, then by the same set of actions it would maximise any fraction of the

\footnotetext{
10 To try to justify the imposition of a rent tax on both new and existing projects on the ground that an auction alone might result in the assumed undesirable imposition of a rent tax on existing projects is not so much as case of the pot calling the kettle black, as the pot calling itself black.

11 It was revealed under FOI that Treasury (2010b) admitted that the RSPT would make some existing miners 'cash-flow negative', thereby threatening the triggering of sanctions under debt covenants.
} 
profits, including the fraction that would be retained under the Brown tax. Therefore, a Brown tax would have no disincentive effects. Dr Henry seemed to hint that he realised that, taken to its logical extreme, this argument was nonsensical, when he noted that, on the same reasoning, a Brown tax of 90 per cent would leave incentives unimpaired. The obvious question then is 'Why not then impose a Brown tax at the rate of $99.999 \ldots$ per cent? ${ }^{\prime 2}$

To model the RSPT on the assumption that it would have zero excess burden ${ }^{13}$ would be to contradict the (later) statement made by Treasurer Swan in his Parliamentary 'Explanatory Memorandum' for MRRT (Swan 2011):

1.32 As the sources of mining rents are difficult to identify separately in practice, the MRRT aims to strike an appropriate balance between recovering a sufficient return to the community from the profits attributable to the underlying resource rents at the valuation point, and recognising that some mining expertise and capital may also be taxed in a process which has regard to realised profits and their equivalents. ${ }^{14}$

Yet, the modelling undertaken by KPMG Econtech for Treasury assumed zero excess burden for the Petroleum Resource Rent Tax and, subsequently, for the RPST. $^{15}$

\section{Modelling royalties}

The Rudd and Gillard governments wanted to abolish state royalties. However, the Policy Transition Group (referred to earlier) recommended that royalties be credited against MRRT liabilities; and, reluctantly, the Gillard government accepted this element. Belatedly, the Gillard government asked the review into the distribution of the GST to suggest ways to discourage rises in royalty rates. (Western Australia and Queensland have since increased royalty rates.) For any company with a sufficiently large MRRT liability, an increase in royalty

12 Treasury Secretary Henry's claim was reported in The Australian (2010). Similarly, a mining tax expert claimed that 'If 100 per cent of the project was a worthwhile investment for the company, 60 per cent of it will be similarly worthwhile, so the [Brown] tax will neither discourage nor encourage investment' (Smith 2010a: 8).

13 In fact DEEWR (2010: 13-4), the government department responsible for the Resource Tax Consultation Panel, claimed that the RSPT would stimulate mining investment because it reduced the risk that the companies would bear (from 100 per cent to 60 per cent). The best one could make of this claim is that it implies that government 'financing' would be cheaper or otherwise more attractive than what was on offer from the finance sector itself - a case of 'market failure', presumably. However, DEEWR (2010: 11) made the sensible point that, because royalties would be credited against any RSPT liabilities, the deterrent effect of royalties would be diminished, if not completely removed.

14 The claim that it is impossible to tax pure rents ex post was made forcefully in Ergas, Harrison and Pincus (2010).

15 'CGE Response' raised no new issues of note that were not present in 'CGE Current'. 
rates would not alter its after-tax profits, but merely shift revenue from the Commonwealth to the states. The desire for revenue is undoubtedly the main motivation for the Commonwealth to try to limit, if not abolish, royalties.

The argument used in AFTS against royalties, and adopted by the Rudd and Gillard governments and their departments, related to the inefficiency of royalties and their high excess burden. Again, the argument is based on elementary economics: royalties are levied on output, not the input, and so shift the cost curve upwards. Thus, royalties reduce output at the relevant margins. But the relevant policy question was 'How inefficient were royalties?'

AFTS and the Rudd and Gillard governments determined that royalties were very inefficient: they imposed much higher excess burden than almost any other tax or levy (when an appropriate equi-revenue comparison was made). For every extra dollar in revenue, the private sector in Australia lost \$1.70: the marginal excess burden of royalties was 70 cents.

In arriving at this startling conclusion, AFTS drew on estimates by KPMG Econtech, of the average and marginal excess burden of the 19 main types of tax or impost, using a large general-equilibrium model called MM900. The work was commissioned and overseen by Treasury. The final report from KPMG Econtech was dated 26 March 2010. ${ }^{16}$

KPMG Econtech reported the average and the marginal excess burdens; AEB and MEB. However, AEB is not a concept discussed commonly in the tax literature in situations with more than one tax. ${ }^{17}$ Instead, I will follow the literature and concentrate on MEB: the ratio of the increase in excess burden to the increase in revenue.

The estimate of an MEB of 70 cents for royalties was startling for two reasons. First, royalties were the main means that states used to garner resource rents from their ownership of sub-soil deposits. So we might expect that royalties would fall heavily on pure rents and so have relatively low excess burdens. Secondly, Australia looms large in the world supply of coal and iron ore and so we might expect that some of the tax burden would be shifted to foreigners. For both intuitions, however, it needs to be kept in mind that, although royalty rates were relatively low (few then above 5 per cent), and by themselves would reduce output little and raise export prices a little, in fact they came on top of other taxes, chiefly company tax and payroll tax.

16 It is not clear from the Treasury website when KPMG Econtech (2010a) was released publicly.

17 The derivation of the partial-equilibrium formula (supply-side only) for AEB is available from the author. 


\section{A 'reality test'}

As a 'reality' test of the KPMG Econtech estimate of 70 cents in the dollar for MEB, I will present a partial-equilibrium model that assumes that all taxes imposed on mining can be simply converted into excise-tax equivalents and cumulated, ${ }^{18}$ and that the export price is endogenous. The first purpose of the model is to estimate the cumulative tax rate that is required to achieve an MEB of 70 cents - this turns out to be unbelievably high. The model is then used to generate a BOTE estimate of the excess burden.

Figure 1 illustrates the Australian market for a mineral, under the following assumptions:

1. All Australian output is exported.

2. Linear supply and demand curves, with slopes $\zeta$ and $-\delta$.

3. The price without the tax is normalised to one.

4. A set of excise taxes is imposed which cumulates to rate $t$.

5. A marginal rise in the tax rate increases tax revenue.

Although assumption 1 is a matter of analytical convenience, it does reflect the fact that the vast bulk of the major Australian mineral outputs are exported. It leads to an underestimate of excess burden, by the (neglected) loss of Australian consumer surplus; however, assumption 4 produces an overestimate, because taxes on company income and payrolls have smaller effects on output than do excises.

With these assumptions, the excess burden of royalties and other imposts on mining in Australia comprises two elements: (1) the excess burden from the supply-side response of the cumulative tax rate, shown as the triangle FEG in Figure 1; and (2) the national gain from shifting some of the revenue burden onto foreigners.

18 For example, the excise-equivalent rate for company tax would be 15 per cent of output for a company tax rate of 30 per cent, if taxable income equalled 50 per cent of sales. 


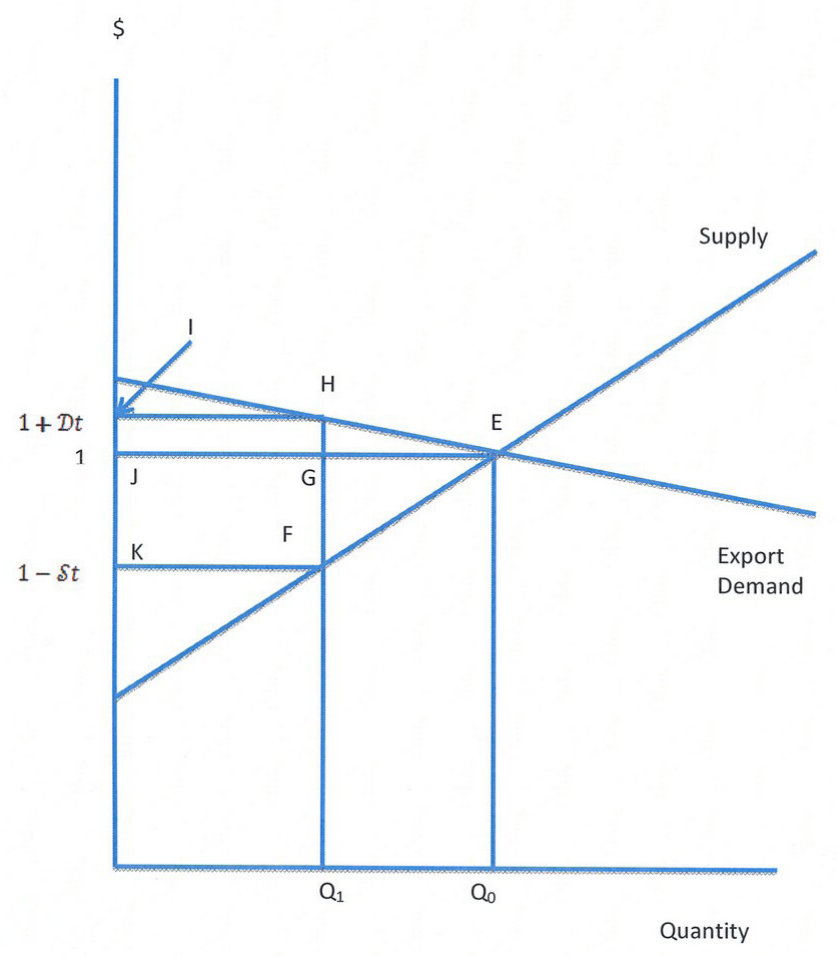

Figure 1: Excess burden of an excise when all output is exported

Notes:

1. The slopes of the supply curve and the demand curves are $\zeta>0$ and $-\delta$.

2. Prior to any tax, price is 1 and quantity is $Q_{0}$.

3. An excise tax is imposed at a rate $t=D t+S t$, where $D=\delta /[\delta+\zeta]$ and $S=\zeta /[\delta+\zeta]$.

4. Under the tax the supply price is $1-S t$, and the demand price is $1+D t$, and the quantity is $Q_{1}$.

5. Excess burden is FEG - HIJG.

Source: Author's own illustration.

These two elements depend on how the tax falls on each side of the market. Define the shares of the tax borne by demanders and suppliers as $\mathrm{D}$ and $\mathrm{S}$ respectively, where $\mathrm{D}=\delta /[\delta+\xi]$ and $\mathrm{S}=\zeta /[\delta+\xi]$ and $\mathrm{D}+\mathrm{S}=1$. These determine the post-tax price received by the producers, equal to 1-St in Figure 1; and the price paid by the foreign demanders, $1+D$. In turn, these determine the overall excess burden, given the tax rate and the relevant elasticities. At $Q_{1}$ in Figure 1 , the elasticity of demand is $\varepsilon\left(Q_{1}\right)=-(1+D t) / \delta Q_{1}<0$; and the supply elasticity is $\eta\left(\mathrm{Q}_{1}\right)=(1-\mathrm{St}) / \zeta \mathrm{Q}_{1}>0$.

It is shown in Ergas and Pincus (2012) that, using $\tau_{s}=s_{t} /\left(1-s_{t}\right)$,

$$
\text { MEB }=s_{t} \eta /\left(1-\tau_{s} \eta\right)-D
$$


The first term in (1) is the MEB on the supply side - a national loss, ${ }^{19}$ the second is the MEB from the endogenous rise in export price - a national gain.

Table C. 3 in 'CGE Current' shows the export demand elasticity as -6. Although neither KPMG Econtech report records the supply elasticity, it can be recovered (with some guesswork) as $1.75 .{ }^{20}$ Thus, foreign demanders would pay 23 per cent of the revenue collected from all taxes falling on mining. ${ }^{21}$ In partial equilibrium, with all output exported, this means that 23 cents must be deducted from an MEB calculated on the supply side only. Therefore, to achieve MEB of 70 cents, as reported in 'CGE Current', an unbelievably high cumulative tax rate is required, as will now be shown.

It is not possible to estimate the cumulative tax rate from 'GCE Current' or 'CGE Response', so an indirect approach is needed. The Minerals Council (2011), when asserting that miners were paying their 'fair share' to the community, claimed that the larger miners were paying around 40 per cent of profits to governments. Presumably, this industry lobbying body would have no incentive towards an understatement, so adopting 40 per cent as the estimate of government levies as a ratio to profits does not seem unduly prejudicial to the 'reality' test of an MEB of 70 cents. $^{22}$ Using expression (1) and the two elasticities (1.75 and -6) shows that an MEB of 70 cents requires a cumulated tax rate of 29 per cent on sales. Arithmetically, on the Minerals Council's claim, that implies profits equal to 73 per cent of sales in 2004-05, which is unbelievably high.

So, to recapitulate: using the partial-equilibrium model illustrated in Figure 1, and parameters from 'CGE Current', an MEB for royalties of 70 cents requires a cumulated tax rate of 29 per cent on sales; and that in turn implies a ratio of mining profits to sales of 73 per cent in 2004-05.

A realistic estimate of the cumulated tax rate on mining sales is around 13 per cent (see Ergas and Pincus 2012). Expression (1) then yields an MEB of 19 per cent on the supply side and minus 23 per cent on the demand side, for an overall MEB of -4 per cent.

\footnotetext{
19 If export demand were perfectly elastic, then MEB would be given by the conventional supply-side formula $\tau \eta /(1-\tau \eta)$, where $\tau=t /(1-t)$. When export demand has elasticity, the supply-side element of the MEB is reduced for two reasons: the fall in supply price is smaller than the rate of tax, $t$; and the marginal revenue gained includes some paid by foreigners.

20 A supply elasticity of around 1.75 means a doubling of prices would increase minerals output to a level three-and-a-half times what it was in 2004-05; and if the prices remain at the new higher level, Australian mining would maintain output at 350 per cent indefinitely.

$21 \quad 1.75 /(6+1.75)=0.23$, and so the export price rises by 23 per cent of the tax rate.

22 However, the ratio of tax to profits may have been higher in 2004-05, the year of the MM900 minerals database - which was before a huge rise in prices. In both reports, KPMG Econtech adjusted the database of 2009-10 to incorporate the lower export prices experienced in 2004-05. This would have had the effect of increasing the supply elasticity and, therefore, the estimate of MEB.
} 
KPMG Econtech ('CGE Current': 27) explained that, due to its assumptions about the supply of capital, the ultimate incidence in MM900 is primarily on labour; and none on capital. For royalties, its own incidence tables show an extremely small burden on labour: less than one-tenth of that needed to exhaust the estimate of the (dollar value of the) excess burden of royalties (using pp. 5 and 59). Read in this way, the incidence table in 'CGE Current' justifies an average excess burden of 4 cents, not the 50 cents reported; and, presumably, an MEB much lower than the 70 cents reported - for example, 5.6 cents, which is 70 times $4 / 50$.

The small negative partial-equilibrium estimate of MEB depends on the terms of trade effect, via export prices. 'CGE Current' reported that the optimum uniform import tariff was 11 per cent; and that, although Australian tariffs were far from uniform and averaged far less than 11 per cent, nonetheless the KPMG Econtech modelling showed that tariffs improved economic welfare. Tariffs reduce imports and so reduce exports, and thus export prices rise: this is the main mechanism through which tariffs improved national welfare in MM900. If so, then it is unexpected that economic welfare did not rise as a result of imposts on mining, which also reduce exports in which Australia has some market power. The simplest formula makes the optimum export tax equal to the inverse of the elasticity of export demand, that is, $1 / 6$ or 17 per cent, which is similar to the 19 per cent estimate of the cumulated rate used earlier. One the face of it, existing imposts on mining seem closer to the optimal export tax than existing tariffs are to the optimal import tax. ${ }^{23}$

Maybe an explanation of the puzzles discussed above lies in unpublished details of the modelling. MM900 was a computable general-equilibrium model, with almost 900 products by 109 industries with access to six primary factors of production within a nested CES production function. At the top level, firms chose between three aggregates: labour, capital and fixed factor. These aggregates respectively reflected choices between low-skilled and high-skilled labour; between structures and other capital; and between land and other fixed factors. Included in the last named were natural resources, assumed in fixed endowment, and specific to each mining industry. Labour was in slightly elastic supply (on the leisure-employment margin); foreign financial capital was in perfectly elastic supply, while domestic savings were proportional to income. MM900 was run in comparative static mode: equilibria were computed independently of any other equilibrium - there were no adjustment paths between equilibria. To estimate average excess burden, the model was run with the tax and without

23 According to Lerner's symmetry theorem, either optimal tax would improve economic welfare. KPMG Econtech estimated the effects of royalties with tariffs in place, and vice versa. So it is even more surprising that, with allegedly very damaging mining taxes in place, tariffs were estimated to improve economic welfare; but not the obverse. 
the tax (or impost); for marginal excess burden, the simulations were with and without a small ( 5 per cent) reduction in the statutory rate. ${ }^{24}$ In both cases, the results were reported as the change in national welfare (compensating variation) divided by the change in total receipts of government. Public budgets were balanced through lump-sum transfers to and from households. The MM900 database, which was for 2009-10, was not made public; nor was the detail of the modelling.

This was an exercise in comparative statics. Therefore, the database had to represent an equilibrium, against which all other simulations were compared. Presumably with that requirement in mind, unspecified adjustments were made for the sharp rise in mineral prices between 2004-05 and 2009-10 (and for the effects of the GFC). ${ }^{25} \mathrm{KPMG}$ Econtech asserted that miners were making excess profits in 2009-10, arising from resource rents; in this, it supported Treasury. Was the mining sector in equilibrium in 2004-05, but not 2009-10? Did the estimate of rents include only pure rents, or did they include quasi-rents? How would such an apportionment be made?

There is another complication involved in embedding a natural resource within a computable general-equilibrium model: natural resources are exhaustible (at least in the long run, in which we will all be dead). Yet the usual assumption in CGE models is that the resource stock is fixed, which suggests that it is modelled as providing a service, rather than a material input; or that there is some activity through which the stock is replenished (on analogy with how depreciation of the reproducible capital stock is offset by gross investment). ${ }^{26}$

\section{Conclusions}

To support the inquiry into the tax system (AFTS), Treasury commissioned and accepted a report from KPMG Econtech (2010a and its supplement 2010b) on the excess burdens of major Australian taxes and government imposts. The modelling used MM900, a large computable general-equilibrium model, run in

\footnotetext{
24 Average Excess Burden or AEB is not a concept well explored in tax theory; in partial equilibrium, the formula for AEB gives double weight to the 'retained' taxes and so the value is 'path dependent'. (The derivation is available from the author.) The interpretations of AEB and MEB present difficulties if revenue falls as a result of the imposition of a tax or its increase.

25 As prices rise and profits increase, the supply elasticity falls, because of the choice of CES form of production function. Thus, with higher minerals prices, that part of the excess burden which is attributable to the supply side falls for two reasons: the royalty rates fall as a proportion of price; and the supply elasticity falls.

26 In addition, a nested production function with constant elasticities of substitution ill fits mining: even if labour and capital were very cheap, it would not be possible to produce a tonne of output using less than a tonne of ore.
} 
comparative static mode. The two estimates that had the most immediate effect on policy related to a new tax that the Commonwealth wished to levy on mining companies — the RSPT — and to an old state-government impost, royalties. ${ }^{27}$

Regarding the new taxes, KPMG Econtech reported zero excess burdens for the Petroleum Resource Rent Tax and subsequently for the RSPT. Actually, this conclusion was arrived at by direct assumption, not a simulation: KPMG Econtech merely asserted that taxes aimed at so-called excess profits have no incentive effects, no excess burden. Eventually Treasurer Swan, in his Parliamentary explanation of the MRRT legislation, contradicted the assertion of zero excess burden, when he explicitly recognised that the rewards to the specialist skills of mining companies (and their financiers) would be taxed in the process of an attempt to tax pure resource rents.

The second, and startling conclusion of KPMG Econtech, was that the existing state royalties imposed massive excess burdens: an average excess burden of 50 cents for each dollar of revenue, and a marginal excess burden of 70 cents. Whereas the conclusion about the purity of 'super profits' taxes was simply assumed, the conclusion about royalties came out of simulations that, naturally enough, relied on assumptions about elasticities and tax rates. Unfortunately, some of the information necessary for external evaluation of the modelling was not included in the KPMG Econtech reports: specifically, the supply elasticities of mining; the share of output that was exported; the adjustments made to the 2009-10 database to account for increases in minerals prices since 2004-05; cost shares; and the tax and royalty rates applied. As to the modelling itself, only a sketch was published.

The conclusion about the inefficiency of royalties has gone largely unchallenged, despite its startling nature, and its apparent inconsistency with aspects of the MM900 model and the modellers' report on the final incidence of royalties. On the contrary, it was endorsed by Commonwealth departments, by Commonwealth officials, and by 20 or so economists who lent unconditional support to the proposal to introduce the Resource Super Profits Tax. Possibly the 20 relied on $a$ priori reasoning: excess profit taxes have no excess burden, whereas an exciselike royalty does. However, numbers matter for policy: that is what quantitative modelling is for, to sort out the numbers and, preferably, provide confidence intervals around them. It is not conducive to good policy when the modelling is in a black box and when outsiders are not provided with a key to get inside.

27 In the national accounts, royalties are a cost of production, not a tax. Ergas and Pincus (2012) suggested that by treating royalties as a tax, the modellers have mistaken a transfer of rents for excess burden. 


\section{References}

AFTS 2010, 'Australia's Future Tax System. Report to the Treasurer', December 2009, Commonwealth of Australia, Department of Treasury, at: http:// taxreview.treasury.gov.au/content/Content.aspx?doc $=$ html/pubs_reports. htm (accessed 29 August 2012).

Argy, F., Borland, J., Cobb-Clark, D., Coelli, T., Denniss, R., Fels, A., Freebairn, J., Grafton, Q., Gruen, N., Guest, R., Hamilton, C., Keating, M., Langmore, J., Mangan, J., Menezes, F., O'Donnell, C., Pannell, D., Quiggin, J., Rao, P., Rolfe, J., Smith, B. and Throsby, D. (2010), Statement [in favour of a resource rent tax to replace royalties]. No longer available at: johnquiggin. com/2010/05/26/resource-rent-tax-statement/

Australian Government, Policy Transition Group (2010), Report to the Australian Government. New Resource Taxation Arrangements, at: http:// www.futuretax.gov.au/content/Publications/downloads/New_Resource_ Taxation_Arrangements_Report.pdf (accessed 29 August 2012).

Department of Education, Employment and Workplace Relations (DEEWR) 2010, 'The Resource Super Profits Tax. A Fair Return to the Nation', Commonwealth of Australia, at: http://www.deewr.gov.au/Department/Documents/Files/ Announcement\%20document.pdf (accessed 29 August 2012).

Ergas, H., Harrison, M. and Pincus, J. 2010, 'Some economics of mining taxes', Economic Papers (29.4): 369-83.

Ergas, H. and Pincus, J. 2012, 'Modelling the excess burden of royalties Revised', unpublished.

KPMG Econtech 2010a, 'CGE Analysis of the Current Australian Tax System. Final Report' (dated 26 March 2010), at: http://taxreview.treasury.gov. $\mathrm{au} / \mathrm{content} / \mathrm{html} / \mathrm{commissioned}$ _work/downloads/KPMG_Econtech_ Efficiency\%20of\%20Taxes_Final_Report.pdf (accessed 29 August 2012).

2010b, 'The Treasury: CGE Analysis of Part of the Government's AFTRS Response', at: http://www.kpmg.com.au/Portals/0/KPMGEcontech-ReportCGE-Analysis-of-part-of-Governments-AFTS-Response.pdf (accessed 29 August 2012).

Minerals Council of Australia 2011, 'Submission to the House of Representatives Economics Committee, Mineral Resource Rent Tax Bill 2011 and related bills', at: http://www.mineralscouncil.com.au/file_upload/files/submissions/ House_Committee_Submission_8_Nov_FINAL.pdf (accessed 29 August 2012). 
Smith, B. 2010, "'Charging for Non-renewable Resource Depletion" or Slimming the Goose: Less Foie Gras but More Golden Eggs?', Paper prepared for the conference: Australia's Future Tax System: A Post-Henry Review, Sydney, 21-23 June.

Swan, W. 2011, The Parliament of the Commonwealth of Australia, House of Representatives, Exploratory Memorandum for the Mineral Resources Rent Tax, at: http://www.ato.gov.au/taxprofessionals/content.aspx?doc=/ content/00286481.htm) (accessed 29 August 2012).

The Australian 2010, 'Mining Tax "Not that Hard" to Understand - Henry', 22 November, at: www.theaustralian.com.au/business/news/mining-tax-notthat-hard-to-understand-henry/story-e6frg90f-1225958471865

Treasury, Department of 2010a, 'Minerals Resource Rent Tax (MRRT) Headline Statement', at: http://archive.treasury.gov.au/documents/2247/PDF/ FOI_2247.pdf (accessed 29 August 2012).

2010b), 'Application of RSPT to Fortescue Metals Group', 23 June. Available at: http://au.news.yahoo.com/thewest/a/-/newshome/8143314/ secret-documents-reveal-mine-tax-truth/

Wilson, Lauren 2012, 'Treasury holdout on MRRT modelling 'unavoidable"', The Australian, 15 March 2012. 